\title{
Employing optical microscopy technique to determine the tissue action of Hamamelis virginiana L. (Hamamelidaceae), Maytenus ilicifolia Mart. ex Reissek (Celastraceae) and Casearia sylvestris Sw. (Salicaceae) tinctures on skin-fixed histological sections of Wistar rats
}

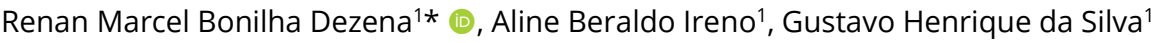 \\ 1'Departamento de Ciências Farmacêuticas, Pontifícia Universidade Católica de Campinas (PUC-CAMPINAS), Campinas, SP, Brasi \\ *Corresponding author: renan_marcel@hotmail.com
}

\begin{abstract}
Objective: In this study, we aimed to determine the action of the tinctures of Hamamelis virginiana, Maytenus ilicifolia, and Casearia sylvestris on tissues. For this, we investigated the histological sections of fixed skin tissue of Wistar rats for the changes in collagen and elastic fibers, epithelial cells, conjunctive cells, epidermal attachments, pigments, and granules using the optical microscopy technique. Since in the literature and published articles, the use of in vivo models, such as Wistar rats, is predominant to evaluate the healing action of herbal medicines. Methods: The tinctures of Hamamelis virginiana, Maytenus ilicifolia, and Casearia sylvestris, and ethanol $70 \%$ (blank) were used. The tinctures were obtained at $10 \%(\mathrm{w} / \mathrm{v})$ through percolation using $70 \%$ ethanol ( $/ \mathrm{v}$ ) as the extraction liquid. This study was conducted in duplicate for each tincture and different incubation times $(4,24$, and $48 \mathrm{~h})$ at $37{ }^{\circ} \mathrm{C}$ in an oven. The slides used in this study (Wistar rat skin) were previously processed at the histology laboratory since the waste material was donated to conduct this experiment. The Research Ethics Committee approved the use of animals of the Life Sciences Center of the Pontifical Catholic University of Campinas (PUC-CAMPINAS) under the protocol approval number $367 / 08$. Before initiating the staining process, the slides were removed from the oven, and the tincture deposited on the slides was removed. Weigert staining was performed subsequently. For semi-quantitative analysis, the histological sections were carefully observed, and the number of collagen and elastic fibers was evaluated based on the following scale: (+) normal fiber presence, (-) slight decrease, (- $)$ moderate decrease, and (- - -) intense decrease. The images were digitally captured to obtain the results using a photomicroscope. Results: The degradation of collagen fibers was best evidenced upon using Hamamelis virginiana tincture, which is concordant with the existing reports in the literature on its healing action via the precipitation of dermal proteins. Maytenus ilicifolia and Casearia sylvestris tinctures exhibited low proteolytic capacity as they only caused degradation of elastic fibers that are more delicate and very different from collagen in their constitution. Therefore, the application of the latter two as healing agents (which acts through precipitating proteins) is limited. Conclusions: This experimental histological model using the optical microscopy technique exhibits the advantage of agility and high efficiency as a simple and powerful approach.
\end{abstract}

Keywords: Hamamelis virginiana. Maytenus ilicifolia. Casearia sylvestris. Healing of Skin Tissue. Optical Microscopy. 


\section{How to cite}

Dezena RMB, Ireno AB, Silva GH. Employing optical microscopy technique to determine the tissue action of Hamamelis virginiana L. (Hamamelidaceae), Maytenus ilicifolia Mart. ex Reissek (Celastraceae) and Casearia sylvestris Sw. (Salicaceae) tinctures on skin-fixed histological sections of Wistar rats. Rev Ciênc Farm Básica Apl. 2021;42:e733. https://doi.org/10.4322/2179-443X.0733

\section{INTRODUCTION}

It is not known exactly who invented the microscope; however, there are reports suggesting that this invention was contributed by Hans Lippershey and Zacharias Janssen in 1590'. Other facts attest that Galileo invented the microscope in 1609, which was named by Giovanni Faber in $1625^{1}$. It was van Leeuwenhoek who then used it for the first time to observe in vivo samples, and Hobert Hooke improved the equipment and compiled all his analyses in 1665, which is described in the book Micrographia ${ }^{1}$.

Light optical microscopy has become an essential aspect of the biological, pharmaceutical, medical, and histological studies, allowing numerous scientific discoveries and advances.

In this context, the microscope is essential, contributing to scientific knowledge to better understand the survival mechanism of living organisms through developing the ability to replace the damaged or dead cells, in addition to tissue repair ${ }^{2}$. To combat the harmful agents that damage cells and tissues, there are a series of events that serve to eliminate these agents, contain the damage, and prepare the cells to survive via replication ${ }^{2}$. The repair of damaged tissue can be divided into two processes: regeneration and cicatrization ${ }^{2}$. Regeneration results in the restoration of damaged tissues, and cicatrization leads to the restoration of the original tissue but involves collagen deposition and scar formation ${ }^{2}$.

Currently, the use of herbal medicines by the Brazilian population has grown, and is mainly associated with the topical application on the skin and repair of the structure and function of the tissue ${ }^{3}$. Advances in the scientific field allowing the marketing of herbal products with guaranteed quality and a strong propensity for the population to undergo less abusive treatment for primary health care are some factors that explains the inclination towards these medicines ${ }^{3}$.

According to the legislation in power in our country, herbal medicine is considered to be obtained using exclusively vegetable raw materials ${ }^{4}$. It is characterized based on the effectiveness and risks associated with its use, as well as the reproducibility and consistency of its quality ${ }^{4}$. Its effectiveness and safety are validated through ethnopharmacological surveys of use, and technoscientific documentation in the form of publications or clinical trials ${ }^{4}$.

Among the wide variety of plant drugs with potential therapeutic effects on skin diseases, Hamamelis virginiana L., Maytenus ilicifolia Mart. ex Reissek and Casearia sylvestris Sw. are considered as superior.

Hamamelis virginiana $\mathrm{L}$. is a shrub or tree that belongs to the family Hamamelidaceae, and its leaves and bark are typically used ${ }^{5}$. It is considered as a medicine for particular diseases, including inflammation, hemorrhoids, varicose veins, phlebitis, still in menorrhagia, dysmenorrhea ${ }^{5}$. It is a peripheral vasoconstrictor and used as a hemostatic agent. Additionally, it exhibits astringent, decongestant, antibacterial, and skin repair properties ${ }^{5-9}$.

Its leaves contain several types of tannins, both condensed and hydrolyzable, and the most abundant one is hamamelitanin ${ }^{10}$. Other compounds have also been isolated and identified, such as dimeric proanthocyanidins ${ }^{10}$.

Maytenus ilicifolia Mart. ex Reissek belongs to the family Celastraceae, and it is a small shrub or tree, perennial, frequently branched from the base, and measures about $5 \mathrm{~m}$ 
in height ${ }^{11}$. It occurs predominantly in the southern region of Brazil and the neighboring countries, including Paraguay, Uruguay, and Eastern Argentina ${ }^{11}$.

As for the chemical constituents isolated from the extracts of different Celastraceae species, it has been observed that they are rich in steroidal, flavonoids, and triterpenoid substances $^{12}$. The therapeutic properties of the plants of Celastraceae family includes antioxidant, insecticidal, cytotoxic, anticancer, antimicrobial, antinociceptive, tissue repair, and antiulcers ${ }^{12-15}$.

Casearia sylvestris Sw. belongs to the family Salicaceae, also grows in Mexico, the islands of the Antilles, and other parts of South America ${ }^{16}$.

The extract, which is obtained as a result of boiling the herbs, exhibits the same pharmacological properties as that of the peels used for fever, as well as for the treatment of herpes, diarrhea ${ }^{16}$. This plant is widely used in folk medicine as an antiseptic, topical anesthetic, and anti-tumor, antiulcer, and antidote drug for treating snake bite. Its chemical constituents include several diterpenes and derivatives of gallic acid ${ }^{17-19}$.

To evaluate the action of Hamamelis virginiana, Maytenus ilicifolia, and Casearia sylvestris tinctures on tissue, in the current study, we aimed to perform in vitro tests on the histological sections of fixed skin tissue of Wistar rats through assessing the changes in collagen and elastic fibers, epithelial cells, conjunctive cells, epidermal attachments, pigments, and granules using an optical microscopy technique.

\section{MATERIALS AND METHODS}

The plant samples were acquired from the supplier Ely Martins and their identification was conducted in the pharmacognosy laboratory. The Research Ethics Committee approved the use of animals of the Life Sciences Center of the Pontifical Catholic University of Campinas (PUC-CAMPINAS) under the protocol approval number 367/08. The slides used in this study (Wistar rat skin) were previously processed the histology laboratory since the waste material was donated to conduct this experiment.

The tinctures of Hamamelis virginiana, Maytenus ilicifolia, and Casearia sylvestris, and ethanol $70 \%$ (blank) were used. The tinctures were obtained at $10 \%(\mathrm{w} / \mathrm{v})$ by percolation using $70 \%$ ethanol $(v / v)$ as the extraction liquid.

The experiment was conducted in duplicate for each tincture and different incubation periods $(4,24$, and $48 \mathrm{~h})$ at $37^{\circ} \mathrm{C}$ in an oven.

\section{Preparation of histological slides}

The histological slides were prepared according to the procedure described as follows:

The dewaxing step, in which the paraffin is removed from the cuts in the slides through incubating them in the following sequence in contact with:

- Xylol I for $10 \mathrm{~min}$;

- Xylol II for $10 \mathrm{~min}$.

The hydration step involves the incubation of the slides in the following sequence in contact with:

- Absolute Ethanol I for 5 min;

- Absolute Ethanol II for 5 min;

- Ethanol 95\% for 5 min;

- Ethanol 80\% for 5 min;

- Ethanol 70\% for 5 min;

- Distilled water for 5 min. 
Before starting the staining process, the slides were removed from the oven, and the tincture deposited on the slides was discarded. Weigert staining was then performed ${ }^{20}$.

The procedure is described as follows:

- Wash in distilled water for $10 \mathrm{~min}$;

- Stain with Weigert or Harris' iron hematoxylin for 4 min;

- Wash in distilled water for $10 \mathrm{~min}$;

- Stain with resorcin-fuchsin for 40 min in a controlled manner using a microscope such that the elastic fibers are stained black. If over-stained, bleach with ammonia water.

- Treat with $95 \%$ ethanol for 3 min;

- Wash in distilled water for $3 \mathrm{~min}$;

- Stain with Van Gieson for 1 min. If over-stained, wash with distilled water. For the bottom to appear yellow, the section should be passed through ethanol with drops of picric acid in a saturated aqueous solution.

The slides were then subjected to the dehydration step in the following sequence in contact with:

- Ethanol 95\% for 5 min;

- Absolute Ethanol I for 5 min;

- Absolute Ethanol II for 5 min;

- Absolute Ethanol III for 5 min.

Subsequently, the diaphanization step was conducted in the following sequence in contact with:

- Xylol I for 5 min;

- Xylol II for 5 min.

Finally, the slides were mounted with Permount, and then covered with coverslips.

\section{Incubation}

Approximately $200 \mu \mathrm{L}$ of tincture or $70 \%$ ethanol was added using a pipette on each dewaxed and hydrated slide. The slides were incubated in an oven at different incubation periods, including 4,24 , and $48 \mathrm{~h}$, at $37^{\circ} \mathrm{C}$.

The slides were coded accordingly as indicated in Table 1:

Table 1. Coding of the histological slides treated with different drug tinctures

\begin{tabular}{cccc}
\hline Incubation Times & $\mathbf{4} \mathbf{h}$ & $\mathbf{2 4} \mathbf{h}$ & $\mathbf{4 8} \mathbf{h}$ \\
\hline \multirow{2}{*}{ Hamamelis virginiana tincture } & HVT & HVT A & HVT B \\
& HVT & HVT A & HVT B \\
Maytenus ilicifolia tincture & MIT & MIT A & MIT B \\
& MIT & MIT A & MIT B \\
Casearia sylvestris tincture & CST & CST A & CST B \\
& CST & CST A & CST B \\
Ethanol 70\% (blank) & BT & BTA & BTB \\
& BT & BTA & BTB \\
\hline
\end{tabular}

\section{Semi-quantitative analysis}

For semi-quantitative analysis, the histological sections were carefully observed, and the number of collagen and elastic fibers was evaluated based on the following scale: $(+)$ normal fiber presence, $(-)$ slight decrease, $(--)$ moderate decrease, and (- - -) intense decrease. The images were captured digitally to obtain the results using a photomicroscope (Nikon Eclipse E200) coupled with a camera (Nikon Coolpix 4500). 


\section{RESULTS}

In the histological analysis performed previously using these slides, it was observed that the most significant changes were related to collagen and elastic fibers. In epithelial and conjunctive cells, epidermal attachments, pigments, and granules, the changes were non-existent or imperceptible, and therefore, semi-quantitative analyses were performed focusing on these two fibers. Regarding collagen, it was observed that only Hamamelis virginiana tincture exhibited proteolytic activity on collagen fibers after 24 and $48 \mathrm{~h}$ of incubation, as shown in Table 2 and Figures 1, 2, and 3.

Regarding the action of the tinctures on elastic fibers, there was again a significant effect of Hamamelis virginiana tincture observed after 4 and $24 \mathrm{~h}$ of incubation. However, a more discreet effect was observed upon using the tinctures of Maytenus ilicifolia and Casearia sylvestris after $24 \mathrm{~h}$ of incubation. All tinctures promoted an intense decrease in elastic fibers after $48 \mathrm{~h}$ of incubation. The results obtained in the semi-quantitative analysis of elastic fibers are presented in Table 3 and the micrographs (Figures 4, 5, and 6).

Table 2. Results of the semi-quantitative analysis of collagen in the histological sections. (+) normal fiber presence, $(-)$ slight decrease, $(--)$ moderate decrease, and (- - $)$ intense decrease.

\begin{tabular}{|c|c|c|}
\hline Incubation Time & Tinctures & Results \\
\hline & Hamamelis virginiana & + \\
\hline \multirow[t]{3}{*}{$4 \mathrm{~h}$} & Maytenus ilicifolia & + \\
\hline & Casearia sylvestris & + \\
\hline & Hamamelis virginiana & - \\
\hline \multirow[t]{3}{*}{$24 \mathrm{~h}$} & Maytenus ilicifolia & + \\
\hline & Casearia sylvestris & + \\
\hline & Hamamelis virginiana & -- \\
\hline \multirow[t]{2}{*}{$48 \mathrm{~h}$} & Maytenus ilicifolia & + \\
\hline & Casearia sylvestris & + \\
\hline
\end{tabular}
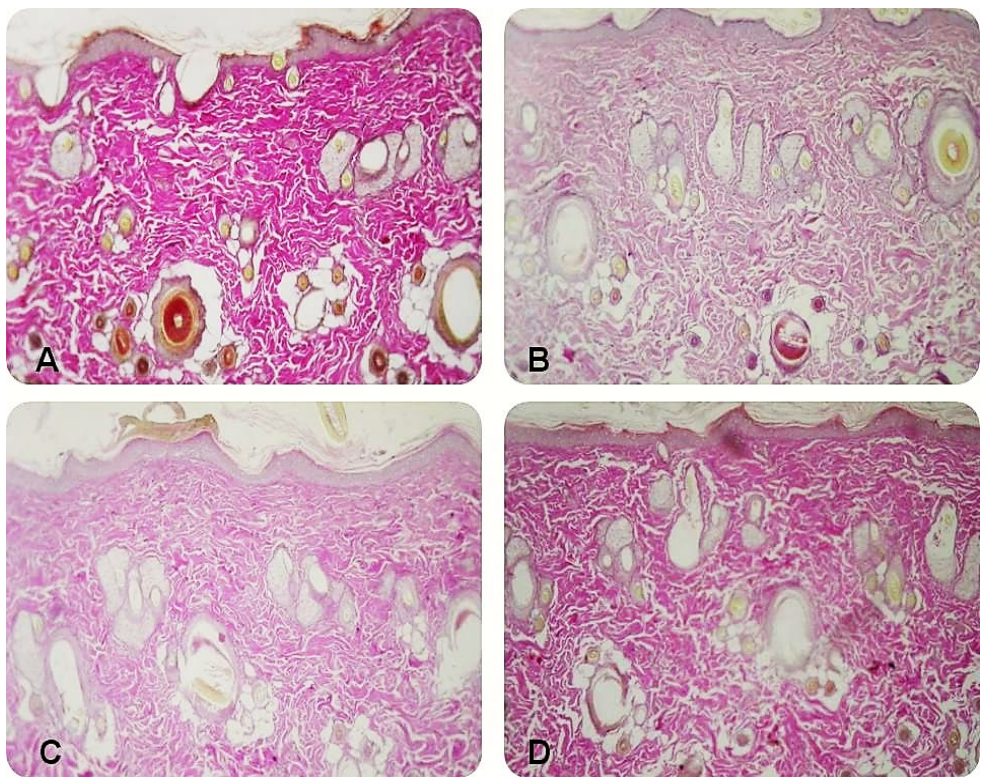

Figure 1. Micrographs of the subcutaneous connective tissue of Wistar rats treated for $4 \mathrm{~h}$ with the tinctures of $\mathrm{A}=$ Blank; $\mathrm{B}=$ Maytenus ilicifolia; $\mathrm{C}=$ Casearia sylvestris; $\mathrm{D}=$ Hamamelis virginiana. $\mathrm{A}$ similar pattern in the organization of collagen fibers was observed in all micrographs (100x magnification). 

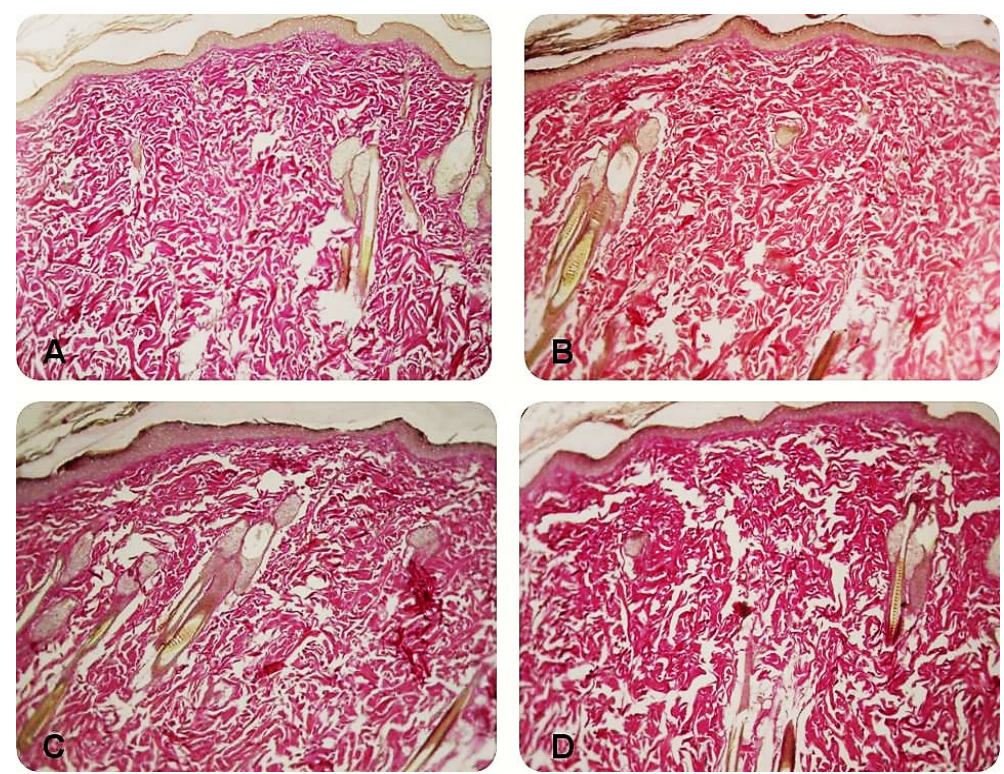

Figure 2. Micrographs of the subcutaneous connective tissue of Wistar rats treated for $24 \mathrm{~h}$ with the tinctures of $\mathrm{A}=$ Blank; $\mathrm{B}=$ Maytenus ilicifolia; $\mathrm{C}=$ Casearia sylvestris; $\mathrm{D}=$ Hamamelis virginiana. $\mathrm{A}$ slight decrease in the number of collagen fibers due to the action of Hamamelis virginiana tincture was observed as presented in D (100x magnification).
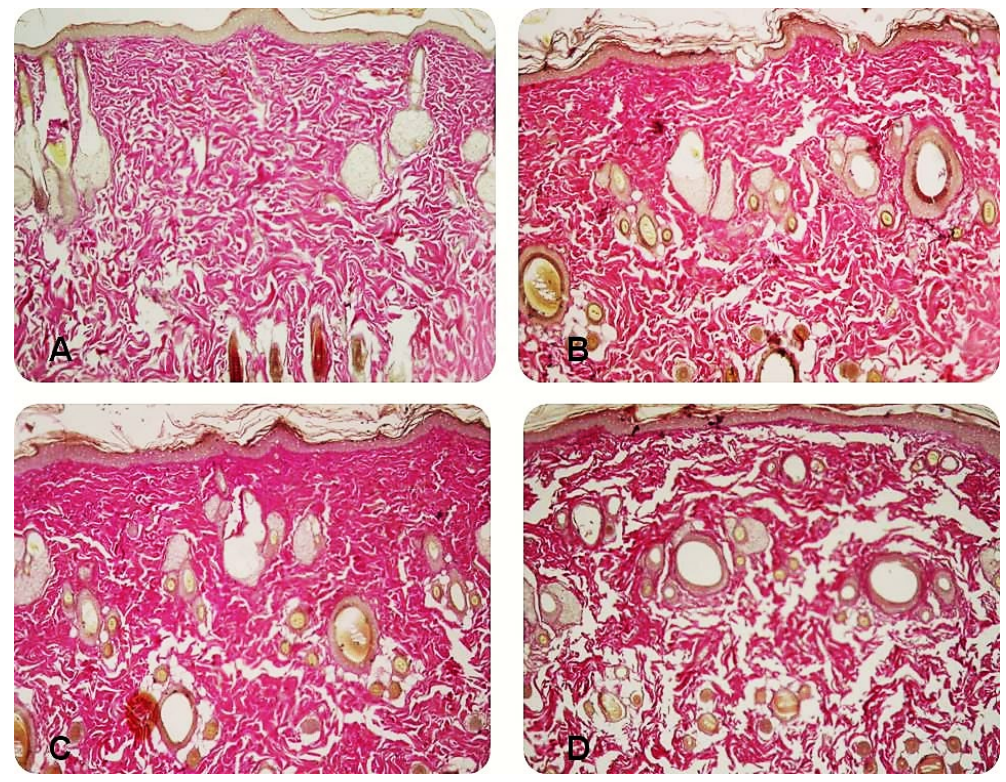

Figure 3. Micrographs of the subcutaneous connective tissue of Wistar rats treated for $48 \mathrm{~h}$ with the tinctures of $\mathrm{A}=$ Blank; $\mathrm{B}=$ Maytenus ilicifolia; $\mathrm{C}=$ Casearia sylvestris; $\mathrm{D}=$ Hamamelis virginiana. $\mathrm{A}$ moderate decrease in the number of collagen fibers due to the action of Hamamelis virginiana tincture was observed as presented in D (100x magnification).

Table 3. Results of the semi-quantitative analysis of elastic fiber in the histological sections. (+) normal fiber presence, (-) slight decrease, (- $)$ moderate decrease, and (- - -) intense decrease.

\begin{tabular}{|c|c|c|}
\hline Incubation Time & Tinctures & Results \\
\hline & Hamamelis virginiana & -- \\
\hline \multirow[t]{3}{*}{$4 \mathrm{~h}$} & Maytenus ilicifolia & + \\
\hline & Casearia sylvestris & + \\
\hline & Hamamelis virginiana & --- \\
\hline \multirow[t]{3}{*}{$24 \mathrm{~h}$} & Maytenus ilicifolia & - \\
\hline & Casearia sylvestris & - \\
\hline & Hamamelis virginiana & --- \\
\hline \multirow[t]{2}{*}{$48 \mathrm{~h}$} & Maytenus ilicifolia & --- \\
\hline & Casearia sylvestris & --- \\
\hline
\end{tabular}



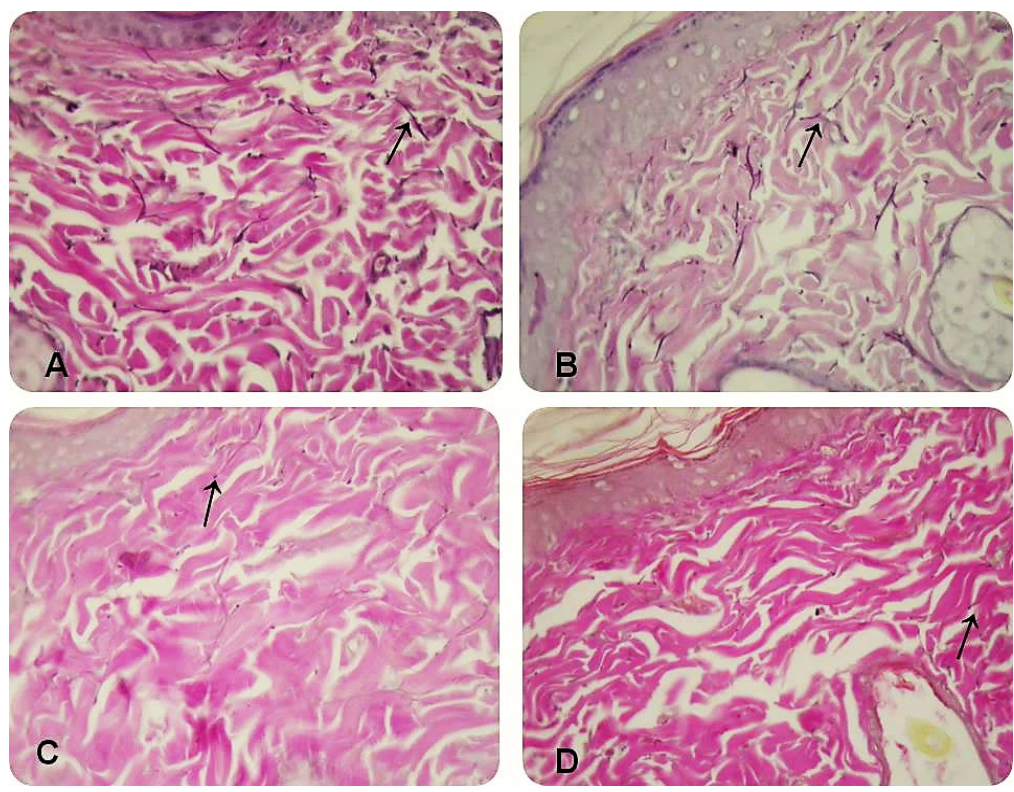

Figure 4. Micrographs of the subcutaneous connective tissue of Wistar rats treated for $4 \mathrm{~h}$ with the

tinctures of $\mathrm{A}=$ Blank; $\mathrm{B}=$ Maytenus ilicifolia; $\mathrm{C}=$ Casearia sylvestris; $\mathrm{D}=$ Hamamelis virginiana $\mathrm{A}$ moderate decrease in the number of elastic fibers due to the action of Hamamelis virginiana tincture was observed as in D. Arrows indicate elastic fibers (400x magnification).
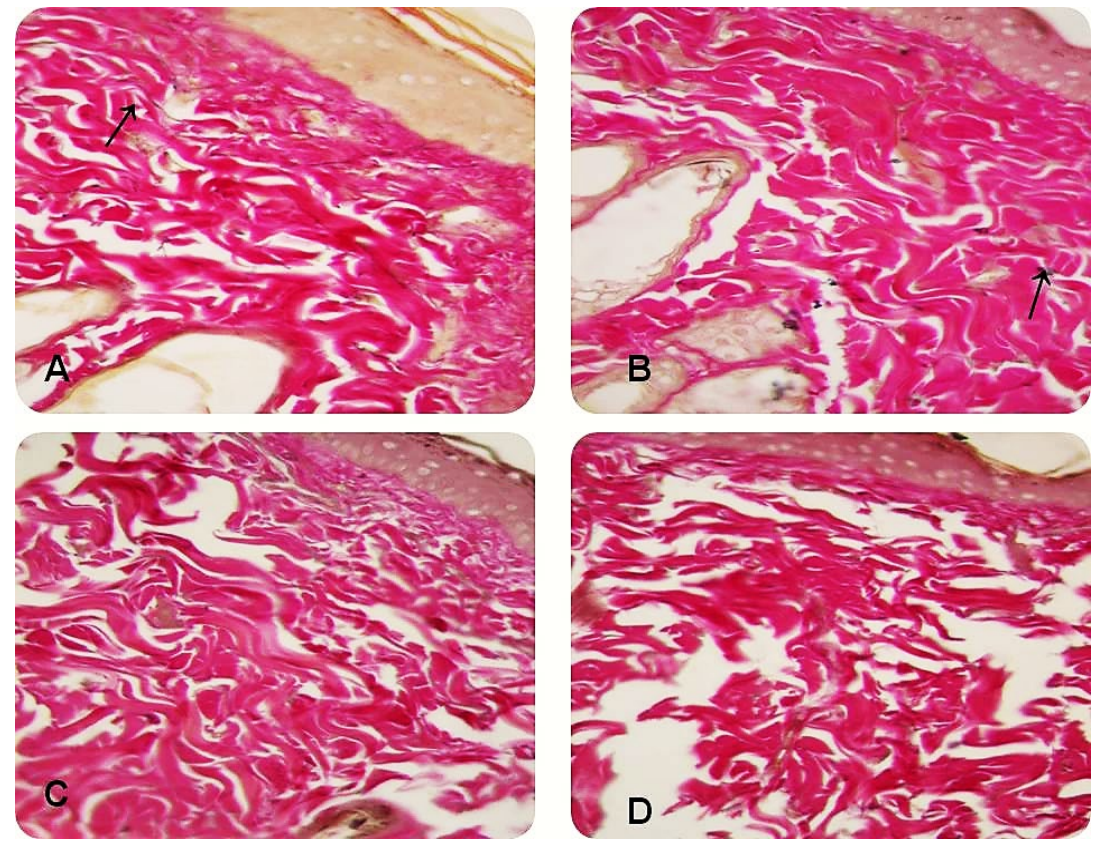

Figure 5. Micrographs of the subcutaneous connective tissue of Wistar rats treated for $24 \mathrm{~h}$ with the tinctures of $\mathrm{A}=$ Blank; $\mathrm{B}=$ Maytenus ilicifolia; $\mathrm{C}=$ Casearia sylvestris; $\mathrm{D}=$ Hamamelis virginiana. $\mathrm{A}$ slight decrease in the number of elastic fibers due to the action of Maytenus ilicifolia and Casearia sylvestris tinctures was observed as in $B$ and $C$, and an intense decrease in the number of elastic fibers due to the action of Hamamelis virginiana tincture was observed as in D. Arrows indicate elastic fibers (400x magnification). 


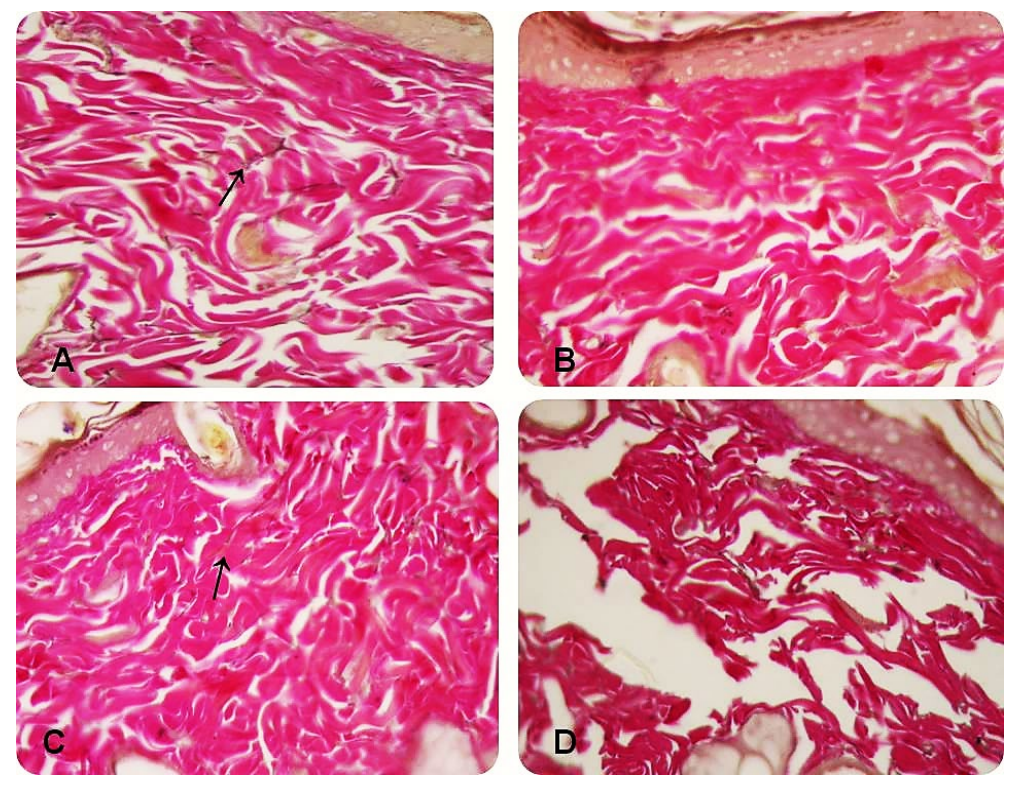

Figure 6. Micrographs of the subcutaneous connective tissue of Wistar rats treated for $48 \mathrm{~h}$ with the tinctures of $\mathrm{A}=$ Blank, $\mathrm{B}=$ Maytenus ilicifolia, $\mathrm{C}=$ Casearia sylvestris, and $\mathrm{D}=$ Hamamelis virginiana. An intense decrease in the number of elastic fibers due to the action of Maytenus ilicifolia, Casearia sylvestris, Hamamelis virginiana tinctures was observed as in B, C, and D. Arrows indicate elastic fibers (400x magnification).

\section{DISCUSSION}

The analysis of collagen and elastic fibers was used as a parameter to verify the action of different tinctures on tissues, since the epithelium was significantly stabilized upon fixation. Healing is based on the replacement of functional parenchyma at the injured site by the deposition of connective tissue. For this reason, some cells, mainly fibroblasts, produce large number of fibers to fill the region. Based on this perspective, herbal medicines, which stimulate the production of fibers, contribute in the healing process.

In the in vitro studies, as proposed in this work, it is described that the substances that cause precipitation of proteins on the surface of the epithelium promote healing, as observed in the case of tannins ${ }^{21-26}$. Therefore, since the test was performed using fixed histological sections, it was not possible to test the stimulation of these substances by the tincture; however, the precipitation capacity (proteolysis) of collagen and elastic fibers was studied, which is directly related to the effectiveness of the healing process. This was evident with the better efficiency of Hamamelis virginiana tincture.

Collagen degradation was more efficient when Hamamelis virginiana tincture was used for 24 and $48 \mathrm{~h}$, and it is a considerable indication, since the healing action of tannins that are present in the leaves of Hamamelis virginiana, is based on the precipitation of proteins on the epithelial surface, thereby forming a film, and this protection helps in healing through decreasing the permeability and exudation of the wound ${ }^{27}$.

The leaves of Hamamelis virginiana exhibit great diversity, as a total of around $10 \%$ tannins form a part of their constitutional phenolic compounds, such as hamamelitannin, aldehydes, and proanthocyanidins. Therefore, they present a more effective result for the degradation of collagen and elastic fibers due to the astringent properties ${ }^{28}$. The main factor that might be related to the less favorable healing effect of Maytenus ilicifolia could be attributed to its chemical composition, as it possesses only one type of tannin (proanthocyanidins) and flavonoids, and therefore, exhibits reduced proteolytic degradation of collagen and elastic fibers. However, a recent study regarding the treatment of wounds using Maytenus ilicifolia extract induced in rats demonstrated another type of mechanism based on the anti-inflammatory, pro-angiogenic, and pro-fibrogenic effects, thereby accelerating the healing process through the activation of metalloprotease 9 , which positively contributes in the keratinization process and closing the epidermis ${ }^{29}$. 
The low effectiveness of Casearia sylvestris may also be associated with its complex chemical composition, comprising diterpene compounds and derivatives of gallic acid. However, due to the absence of the main phytochemical tannin in its leaves that helps in the process of skin restoration, our results corroborate with those of a published report on the effectiveness of the topical application of Casearia sylvestris solutions in skin lesions induced in mice, and suggest that there were no statistically significant differences when comparing the control group with the test group that used the Casearia sylvestris solutions at the concentrations of $1 \%$ and $10 \%{ }^{30,31}$.

However, no epithelial precipitation was observed because keratinocytes produce a large amount of keratin, a very rigid protein, and thus, they were stabilized using the slide fixation process. Therefore, it was challenging to break it down using any agent.

The results obtained in the semi-quantitative analysis of elastic fibers is also an indicator, such as collagen. However, they are more delicate and has a very different structure from collagen, and thus, they can be degraded more easily, which was quite evident from the results of the present study.

The permanence of epithelial and conjunctive cells, epidermal attachments, pigments, and granules was expected to be unchanged upon the application of the tinctures because they exhibit relatively limited proteolytic and fibrinolytic capacities. It was also noted that all these structures are more stable or exhibit variable and very stable constitutions.

It should be noted that the in vitro experimental model has limitations but serves as an essential indicator of the efficiency of the used tinctures, especially that of Hamamelis virginiana, in the tissue healing process. Evidently, in an in vivo model, for the success of the healing process, an increase in the number of collagen and elastic fibers is expected due to the stimulation of fibroblasts and other cells.

\section{CONCLUSION}

Based on the results of this study, we conclude that the degradation of collagen fibers was best evidenced upon using Hamamelis virginiana tincture, which is concordant with the existing reports on its healing action, through the precipitation of dermal proteins. Maytenus ilicifolia and Casearia sylvestris tinctures exhibited low proteolytic activities because they only cause degradation of elastic fibers, which are more delicate, and different from collagen. Therefore, the application of the latter two as healing agents (which acts through precipitating the proteins) is limited.

In epithelial and conjunctive cells, epidermal attachments, pigments, and granules, the tinctures did not develop. However, in the experimental model, any alteration in these parameters, whether related to the digestion of their components or affinity to the tinctures used in the staining technique. It should be noted that the conclusions presented in this study are only indicative of the action of Hamamelis virginiana, Maytenus ilicifolia, and Casearia sylvestris tinctures on tissues using an in vitro experimental setup, and therefore, in vivo studies are necessary to guarantee efficiency and safety before using them in therapy.

This experimental histological model using the optical microscopy is essential because in the literature and published articles, only in vivo models, such as Wistar rats, have been used to evaluate the healing action of herbal medicines. However, we chose the in vitro model for its agility and feasibility of using optical microscopy as a simple and powerful tool.

\section{REFERENCES}

1. Wollman AJM, Nudd R, Hedlund EG, Leake MC. From animaculum to single molecules: 300 years of the light microscope. Open Biol. 2015;5(4):150019. http://dx.doi.org/10.1098/rsob.150019. PMid:25924631.

2. Kumar V, Abbas AK, Fausto N, Aster JC. Robbins and Cotran pathologic basis of disease. 10th ed. USA: Elsevier health sciences; 2020.

3. Melro JCL, et al. Ethnodirigid study of medicinal plants used by the population assisted by the "programa de saúde da família" (Family health program) in Marechal Deodoro-Al, Brazil. Braz J Biol. 2020;80(2):410-23. http://dx.doi.org/10.1590/1519-6984.214039. PMid:31482971. 
4. Brasil. Ministério da Saúde. Agência Nacional de Vigilância Sanitária - ANVISA. Resolução RDC n 14, de 31 de março de 2010. Dispõe sobre o registro de medicamentos fitoterápicos. Diário Oficial da União; Brasília.

5. European Medicines Agency. Assessment report on Hamamelis virginiana L., cortex, Hamamelis virginiana L. folium, Hamamelis virginiana L., folium et cortex aut ramunculus destillatum [Internet]. London: European Medicines Agency; 2009 [cited 2021 Apr 16]. 47 p. Available from: http://www.emea.europa.eu

6. Deters A, Dauer A, Schnetz E, Fartasch M, Hensel A. High molecular compounds (polysaccharides and proanthocyanidins) from Hamamelis virginiana bark: influence on human skin keratinocyte proliferation and differentiation and influence on irritated skin. Phytochemistry. 2001;58(6):949-58. http://dx.doi.org/10.1016/S0031-9422(01)00361-2. PMid:11684194.

7. Wolff $\mathrm{HH}$, Kieser M. Hamamelis in children with skin disorders and skin injuries: results of an observational study. Eur J Pediatr. 2007;166(9):943-8. http://dx.doi.org/10.1007/s00431-006-0363-1. PMid:17177071.

8. Solis-Arevalo KK, Garza-Gonzalez MT, Lopez-Calderon HD, Solis-Rojas C, Arevalo-Nino K. Electrospun membranes based on schizophyllan-pvoh and hamamelis virginiana extract: antimicrobial activity against microorganisms of medical importance. IEEE Trans Nanobioscience. 2019;18(4):522-7. http://dx.doi.org/10.1109/TNB.2019.2924166. PMid:31226081.

9. Abbas TF, Abbas MF, Lafta AJ. Antibacterial activity and medical properties of Witch Hazel Hamamelis virginiana. Ann Trop Med Public Health. 2020;23(11). http://dx.doi.org/10.36295/ASRO.2020.231146.

10. Simões CMO, Schenkel EP, de Mello JCP, Mentz LA, Petrovick PR. Pharmacognosy: from the natural product to the medicine. Porto Alegre: Artmed; 2016

11. Carvalho-Okano RM. Estudos taxonomicos do genero Maytenus Mol. emend. Mol. (celastraceae) no Brasil extra-amazonico [tese]. Campinas: UNICAMP; 1992.

12. Veloso CC, Soares GL, Perez AC, Rodrigues VG, Silva FC. Pharmacological potential of maytenus species and isolated constituents, especially tingenone, for treatment of painful inflammatory diseases. Brazilian J Pharmacogn. 2017;27(4):533-40. http://dx.doi.org/10.1016/j.bjp.2017.02.006.

13. Silva JL, et al. Evaluation of antiulcerogenic activity of Maytenus truncata Reiss (Celastraceae). Brazilian J Pharmacogn. 2005;15(1):30-5. http://dx.doi.org/10.1590/s0102-695x2005000100007.

14. Hernandes $C$, et al. Anticancer Activities of the Quinone-Methide Triterpenes Maytenin and 22- $\beta$ hydroxymaytenin Obtained from Cultivated Maytenus ilicifolia Roots Associated with DownRegulation of miRNA-27a and miR-20a/miR-17-5p. Molecules. 2020;25(3):1-19. http://dx.doi.org/10.3390/molecules25030760. PMid:32050628.

15. Paulino N, Vieira GF, da Silva Braga MI, de Lima Carvalho LB, Bernardo IP, Nogueira VF. Development of effervescent medical powder containing Maytenus ilicifolia extract Mart. ex Reissek for treatment of gastric disorders. Int J Phytocos Nat Ingred. 2019;6(1):14. http://dx.doi.org/10.15171/ijpni.2019.14.

16. Esteves I, et al. Gastric antiulcer and anti-inflammatory activities of the essential oil from Casearia sylvestris Sw. J Ethnopharmacol. 2005;101(1-3):191-6. http://dx.doi.org/10.1016/j.jep.2005.04.020. PMid:15994044.

17. Espindola LS, e Vasconcelos Júnior JR, de Mesquita ML, Marquié P, de Paula JE, Mambu L, Santana JM. Trypanocidal activity of a new diterpene from Casearia sylvestris var. lingua. Planta Med. 2004;70(11):1093-5. http://dx.doi.org/10.1055/s-2004-832655. PMid:15549670.

18. Alonso J. Tratado de fitofármacos y nutracéuticos. Santa Fe, Argentina: Corpus Libros Rosario; 2004.

19. Bueno PCP, et al. Infraspecific chemical variability and biological activity of Casearia sylvestris from different brazilian biomes. Planta Med. 2021;87(01/02):148-159. https://doi.org/10.1055/a-1301-0183.

20. de Tolosa EMC, Rodrigues CJ, Behmer OA, de Freitas AG No. Manual of techniques for normal and pathological histology. São Paulo: Manole Ltda; 2003.

21. Jorge Neto J, Fracasso JF, Camargo Neves MCL, Santos LE, Banuth VL. Treatment of varicose ulcers and skin lesions with Calendula officinalis L. and / or Stryphnodendron barbaderiman (Vellozo) Martius. Rev Ciênc Farm. 1996;17:181-6.

22. Heijmen FH, du Pont JS, Middelkoop E, Kreis RW, Hoekstra MJ. Cross-linking of dermal sheep collagen with tannic acid. Biomaterials. 1997;18(10):749-54. http://dx.doi.org/10.1016/S01429612(96)00202-5. PMid:9158858. 
23. Adamczyk B, Simon J, Kitunen V, Adamczyk S, Smolander A. Tannins and their complex interaction with different organic nitrogen compounds and enzymes: old paradigms versus recent advances. ChemistryOpen. 2017;6(5):610-4. http://dx.doi.org/10.1002/open.201700113. PMid:29046854.

24. Huang Q, Liu X, Zhao G, Hu T, Wang Y. Potential and challenges of tannins as an alternative to infeed antibiotics for farm animal production. Anim Nutr. 2018;4(2):137-50. http://dx.doi.org/10.1016/j.aninu.2017.09.004. PMid:30140753.

25. Yusiati LM, Kurniawati A, Hanim C, Anas MA. Protein binding capacity of different forages tannin. IOP Conf Ser Earth Environ Sci. 2018;119:012007. http://dx.doi.org/10.1088/1755-1315/119/1/012007

26. Das AK, Islam MN, Faruk MO, Ashaduzzaman M, Dungani R. Review on tannins: extraction processes, applications and possibilities. S Afr J Bot. 2020;135:58-70.

http://dx.doi.org/10.1016/j.sajb.2020.08.008.

27. Cano A, Andres M, Chiralt A, González-Martinez C. Use of tannins to enhance the functional properties of protein based films. Food Hydrocoll. 2020;100:105443.

http://dx.doi.org/10.1016/j.foodhyd.2019.105443.

28. Teixeira CS. Hamamelis virginiana: composição fitoquímica, usos na medicina tradicional, propriedades biológicas e toxicologia [dissertação]. Covilhã: Universidade da Beira Interior; 2019. [cited 2021 Apr 16]. Available from: http://hdl.handle.net/10400.6/8612.

29. de Moura FBR, et al. Wound healing activity of the hydroethanolic extract of the leaves of Maytenus ilicifolia Mart. Ex Reis. J Tradit Complement Med. 2021. Epub ahead of print. http://dx.doi.org/10.1016/j.jtcme.2021.03.003.

30. de Oliveira Alves JE, de Medeiros JAP, Catelli MF. Assessment of healing action of guaçatonga (Casearia sylvestris Sw.) on experimental induced wounds in mice. Nucl Anim. 2016;8(1):15-20.

31. Da Silva SL, Chaar JS, Yano T. Chemotherapeutic potential of two gallic acid derivative compounds from leaves of Casearia sylvestris Sw (Flacourtiaceae). Eur J Pharmacol. 2009;608(1-3):76-83. http://dx.doi.org/10.1016/j.ejphar.2009.02.004. PMid:19222998.

\section{Authors' contributions}

RMBD: Conceptualization, Methodology, Investigation, Formal analysis, Original draft preparation. ABI: Conceptualization, Methodology, Investigation, Formal analysis, Original draft preparation. GHS: Review \& Editing; Supervision. 